\title{
The Effect of Thymosin Alpha I on Severe Acute Pancreatitis in Rats
}

\author{
ZL Qiu, ZJ Wang, JK Huang, HH Dou, CM Zhen, F Cheng
}

\begin{abstract}
Objective: To observe the effect of thymosin alpha l (Tal) on severe acute pancreatitis (SAP) in rats.

Methods: Twenty-four adult male Sprague-Dawley rats were randomly divided into three groups (eight in each group): control group (Group A), SAP group (Group B) and Tal treatment group (Group C). Animal models of SAP were made by retrograde injection of $5 \%$ sodium taurocholate into the biliopancreatic duct. Rats in Group C were treated with Tal (6 mg/kg) via intraperitoneal administration prior to SAP modelling. Eight rats in each group were sacrificed at 12 hours, respectively, after modelling. The serum levels of amylase, tumour necrosis factor- $\alpha(T N F-\alpha)$, interleukin-l $\beta(I L-l \beta)$ and interleukin-6 (IL-6) were detected in each group. The pathological scores of the tissue in the pancreas head were observed by light microscopy.

Results: The levels of serum amylase of Group B were $6378 \pm 538 \mathrm{U} / \mathrm{L}$, which were significantly higher than those $(4587 \pm 478 \mathrm{U} / \mathrm{L})$ of Group $C(\mathrm{p}<0.05)$. The levels of serum TNF- $\alpha$ of Group B were $360.32 \pm 28.67 \mathrm{pg} / \mathrm{mL}$, which were higher than those $(269.99 \pm 26.11 \mathrm{pg} / \mathrm{mL})$

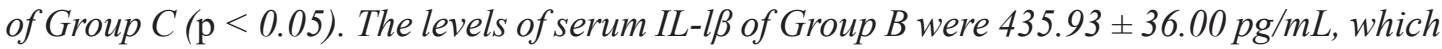
were higher than those $(312.42 \pm 17.89 \mathrm{pg} / \mathrm{mL})$ of Group $C(\mathrm{p}<0.05)$. The levels of serum $I L-6$ of Group B were $433.90 \pm 28.36 \mathrm{pg} / \mathrm{mL}$, which were higher than those $(289.98 \pm 23.00 \mathrm{pg})$ $m L)$ of Group C (p < 0.05). The pancreatic pathological scores of Group B were 13.34 \pm 2.19 , which were higher than those $(6.39 \pm 1.86)$ of Group $C(\mathrm{p}<0.05)$.

Conclusion: Thymosin alpha 1 could decrease proinflammatory cytokines and reduce pancreas injury and had a protective effect in rats with SAP. This provides a new strategy for the clinical treatment of SAP.
\end{abstract}

Keywords: Effect, severe acute pancreatitis, thymosin alpha 1, tumour necrosis factor- $\alpha$

\section{Estudios sobre el efecto de la timosina alfa 1 sobre la pancreatitis aguda grave en ratas}

ZL Qiu, ZJ Wang, JK Huang, HH Dou, CM Zhen, F Cheng

\section{RESUMEN}

Objetivo: Observar el efecto de la timosina alfa l (Tal) sobre la pancreatitis aguda grave (PAG) en ratas.

Métodos: Veinticuatro ratas Sprague-Dawley adultas machos fueron divididas aleatoriamente en tres grupos (ocho en cada grupo): grupo de control (grupo A), grupo de PAG (grupo B) y

From: Department of Emergency Surgery, The First Affiliated Hospital of Bengbu Medical College, Bengbu, Anhui Province, 233000, China.
Correspondence: Dr ZJ Wang, Department of Emergency Surgery, The First Affiliated Hospital of Bengbu Medical College, Bengbu, Anhui Province, 233000, China. Email: ahbyfywzj@163.com 
grupo de tratamiento con Tal (grupo C). Los modelos animales de PAG fueron creados mediante inyección retrógrada de taurocolato de sodio al $5 \%$ en el conducto biliopancreático. Las ratas del grupo $C$ se trataron con $T \alpha 1(6 \mathrm{mg} / \mathrm{kg})$ via administración intraperitoneal antes del modelado de PAG. Las ocho ratas en cada grupo fueron sacrificadas a las 12 horas, respectivamente, después del modelado. Los niveles séricos de amilasa, factor- $\alpha$ de necrosis tumoral (TNF- $\alpha$ ), interleucina- $\beta$ (Il- $\beta$ ) e interleucina-6 (IL-6) fueron detectados en cada grupo. Las puntuaciones patológicas del tejido en la cabeza del páncreas fueron observadas mediante microscopía de luz.

Resultados: Los niveles de amilasa sérica del grupo B fueron $6378 \pm 538 \mathrm{U} / \mathrm{L}$, y resultaron significativamente más altos ( $\mathrm{p}<0.05)$ que los niveles $4587 \pm 478 \mathrm{U} / \mathrm{L}$ del grupo C. Los niveles séricos de TNF- $\alpha$ del grupo B fueron $360.32 \pm 28.67 \mathrm{pg} / \mathrm{mL}$, y resultaron ser más altos $(\mathrm{p}<0.05)$ que los $269.99 \pm 26.11 \mathrm{pg} / \mathrm{mL}$ del grupo $C$. Los niveles séricos de Il- $\beta$ del grupo $B$ fueron $435.93 \pm 36.00 \mathrm{pg} / \mathrm{mL}$, y fueron más altos $(\mathrm{p}<0.05)$ que los $312.42 \pm 17.89 \mathrm{pg} / \mathrm{mL}$ ) del grupo C. Los niveles de suero IL-6 del grupo B fueron $433.90 \pm 28.36 \mathrm{pg} / \mathrm{mL}$, y resultaron ser más altos $(\mathrm{p}<0.05)$ que los $289.98 \pm 23.00 \mathrm{pg} / \mathrm{mL}$ del grupo C. Las puntuaciones patológicas pancreáticas del grupo B fueron $13.34 \pm 2.19$, y resultaron ser más altas $(\mathrm{p}<0.05)$ que las puntuaciones $6.39 \pm 1.86$ del grupo $C$.

Conclusión: La timosina alfa pudo disminuir las citoquinas proinflamatorias y reducir la lesión del páncreas, y tuvo un efecto protector en las ratas con PAG. Esto ofrece una nueva estrategia para el tratamiento clínico de PAG.

Palabras clave: Efecto, pancreatitis aguda grave, timosina alfa 1, factor de necrosis tumoral- $\alpha$

West Indian Med J 2018; 67 (3): 239

\section{INTRODUCTION}

Severe acute pancreatitis (SAP) is a severe stage in the development of acute pancreatitis, often accompanied by significant organ dysfunction, walled-off necrosis, pseudocyst or other complications. Severe acute pancreatitis is a dangerous disease with a rapid onset and a long duration, requiring complex treatment. It remains a disease with a relatively high mortality, accompanied by many complications, and it requires relatively high treatment costs (1). The occurrence and development of SAP course will activate inflammatory cytokines which promote the development of systemic inflammatory response syndrome (SIRS) and even multiple organ dysfunction syndrome (MODS) and, finally, may cause death (2). According to statistics, the mortality rate is up to $10-20 \%$ (3).

Thymosin alpha 1 (Ta1) is an immunologically active peptide which is a cellular immune-enhancing agent that has the function of promoting secretion of cytokines and augmenting lymphocyte function in vivo (4). Using T $\alpha 1$ to treat Sprague-Dawley (SD) rats with SAP, this study investigated the effect of T $\alpha 1$ on pancreatic injuries in SAP and provides new ideas for SAP clinical therapy.

\section{SUBJECTS AND METHODS}

All procedures involving animals were reviewed and approved by the Institutional Animal Care and Use Committee of The First Affiliated Hospital of Bengbu Medical College, Anhui Province, China. The animal protocol was designed to minimize pain or discomfort to the animals.

\section{Experimental animals}

Twenty-four adult male SD rats of clean grade, weighing 210-80 g, were obtained from the Laboratory Animal Centre of Zhejiang Province, China.

\section{Animal grouping and severe acute pancreatitis model-making}

Twenty-four SD rats were randomly divided into three groups (eight in each group): control group (Group A), SAP group (Group B), Ta1 treatment group (Group C). All rats were fasted for 12 hours before surgery with free drinking water. The rats were fixed on the operating table. After skin preparation and iodine disinfection, they were anaesthetized by isoflurane, an inhalation anaesthetic drug, purchased from Abbott Laboratories SA in Shanghai, China. After disinfection of the skin, 
ventral midline incisions of $5-6 \mathrm{~cm}$ in the abdominal cavity of the rats were made. After duodenum and pancreas in rats in Group A were turned off, incisions closed. Rats in Group B were injected retrograde with $5 \%$ sodium taurocholate $(0.1 \mathrm{~mL} / 100 \mathrm{~g}$, purchased from Sigma, United States of America) through the pancreaticobiliary ducts at a uniform and slow speed in order to prepare SAP animal models. Five hours before SAP animal model-making, rats in Group $\mathrm{C}$ received intraperitoneal injection of T $\alpha 1(6 \mathrm{mg} / \mathrm{kg})$, which was purchased from Shanghai Industrial United Group Great Wall Pharmaceutical Co Ltd, China.

\section{Indicators of observation and detection methods}

Rats in each group were killed 12 hours after SAP models were successfully made. Blood samples were obtained from the abdominal aorta. Histological examination was conducted on fixed portions of pancreatic tissue.

Detection of tumour necrosis factor- $\alpha$, interleukin-l $\beta$ and interleukin-6 in sera of rats in each group

Tumour necrosis factor- $\alpha$ (TNF- $\alpha$ ), interleukin-1 $\beta$ (IL$1 \beta$ ) and interleukin-6 (IL-6) in the sera of rats in each group were detected using enzyme-linked immunosorbent assay (kits were purchased from Shanghai Senxiong Biotech Industrial Co Ltd, China).

\section{Determination of serum amylase in each group}

A fully automatic biochemical analyser was used to detect the levels of serum amylase.

\section{Histopathological examination of the pancreatic head}

Light microscopic examination: samples of the pancreatic head were fixed conventionally in $10 \%$ formalin solution, embedded in paraffin, cut into slices and stained with haematoxylin-eosin. The pathological score of the pancreatic head was calculated using the methods of Schmidt et al (5).

\section{Statistical analysis}

All the experimental data were expressed as mean \pm standard deviation $(\bar{x} \pm s)$. Statistical software SPSS 16.0 was used for statistical analysis. Analysis of variance and q test were used. When $p$ was below 0.05 , the result was considered statistically significant.

\section{RESULTS}

Changes in serum levels of tumour necrosis factor- $\alpha$, interleukin-1 $\beta$, interleukin-6 and amylase

The serum levels of TNF- $\alpha$, IL-1 $1 \beta$, IL- 6 and amylase in Group C were significantly lower than those in Group B (Table 1). The difference was statistically significant $(p<0.05)$.

The serum levels of TNF- $\alpha$, IL-1 $\beta$, IL- 6 and amylase in Group B were significantly higher than those in Group A. The difference was statistically significant $(p<0.05)$.

\section{Histopathological changes in the pancreatic head}

Pancreatic head tissues in Group B showed extensive inflammatory cell infiltration, alveolar oedema, interstitial haemorrhage and necrosis. Table 2 shows that Group B's pathological scores were significantly higher than Group A's $(p<0.05)$. Pancreatic head tissues in Group C also showed cell infiltration, tissue oedema and haemorrhage, but compared with Group B, the situation was less severe. Group C's pathological scores were significantly lower compared with Group B's $(p<0.05)$. Pancreatic head tissues in Group A showed no significant pathological changes at all time points.

\section{DISCUSSION}

The pathogenesis of SAP is complicated and ambiguous with critical conditions and difficult treatment. Until now, specific and effective treatment has not been found yet. It is currently considered that TNF- $\alpha$, IL- $1 \beta$, IL-6 and other factors are potent media through which SAP causes
Table 1: Serum levels of tumour necrosis factor- $\alpha$, interleukin-1 $\beta$, interleukin- 6 and amylase in the groups $(\mathrm{n}=8 ; \bar{x} \pm s)$

\begin{tabular}{llllll}
\hline Group & Point in time & $\begin{array}{l}\text { Tumour necrosis } \\
\text { factor- } \boldsymbol{\alpha}(\mathbf{p g} / \mathbf{m L})\end{array}$ & $\begin{array}{l}\text { Interleukin-1/ } \\
(\mathbf{p g} / \mathbf{m L})\end{array}$ & $\begin{array}{l}\text { Interleukin-6 } \\
(\mathbf{p g} / \mathbf{m L})\end{array}$ & Amylase (U/L) \\
\hline A & 12 hours & $160.46 \pm 16.42$ & $101.19 \pm 14.02$ & $122.25 \pm 18.16$ & $1107 \pm 84$ \\
B & 12 hours & $360.32 \pm 28.67^{*}$ & $435.93 \pm 36.00^{*}$ & $433.90 \pm 28.36^{*}$ & $6378 \pm 538^{*}$ \\
C & 12 hours & $269.99 \pm 26.11^{\# *}$ & $312.42 \pm 17.89^{\# *}$ & $289.98 \pm 23.00^{\# *}$ & $4587 \pm 478^{\# *}$ \\
\hline
\end{tabular}

* Compared with Group A, $p<0.05$.

\# Compared with Group B, $p<0.05$.
Table 2: Pancreatic pathological scores in the groups $(\mathrm{n}=8 ; \bar{x} \pm s)$

\begin{tabular}{lll}
\hline Group & Point in time & $\begin{array}{l}\text { Scores of pancre- } \\
\text { atic pathology }\end{array}$ \\
\hline A & 12 hours & $0.44 \pm 0.22$ \\
B & 12 hours & $13.34 \pm 2.19^{*}$ \\
C & 12 hours & $6.39 \pm 1.86^{\# *}$ \\
\hline
\end{tabular}

* Compared with Group A, $p<0.05$.

\# Compared with Group B, $p<0.05$. 
SIRS (6). Tumour necrosis factor- $\alpha$ is the first inflammatory mediator enhanced by SAP and plays a central role (7). In addition, TNF- $\alpha$ can directly induce protease activation and pancreatic tissue necrosis (8). As an initiation factor, TNF- $\alpha$ can induce the expression of the gene itself. In addition, it can then cause waterfall-like chains and a cascading effect (9), prompting the body to release IL-6, IL-8, platelet-activating factor, oxygen-free radicals, prostacyclin, bradykinin etc. The latter has feedback on neutrophils and monocyte-macrophage cell system which further produce more inflammatory mediators, expanding its inflammatory effects and forming a complex and highly coupled network system. This waterfall-like cascade effect, out of control, plays a key role in SAP pancreatic tissue continuous necrosis, leading to changes in the structure and function of pancreatic tissues, tissue necrosis, and SIRS, acute respiratory distress syndrome, disseminated intravascular coagulation, MODS and other pathophysiologic changes. In this experiment, 12 hours after models were established successfully, rats in Group B showed significantly increased serum levels of amylase and inflammatory cytokine levels. Inflammatory cell infiltration, oedema and necrosis can be observed in pancreatic tissues.

Thymosin is widely found in human tissues and cells. It plays a very important role in regulating the body's development and immune function. Thymosin $\alpha 1$ is the most active component of thymopeptide. It contains 28 amino acids of which the only modification is the $\mathrm{N}$-terminal acetylation and plays an important regulatory role in tumour immunity and cellular immunity (10). Acting on thymocytes, T $\alpha 1$ stimulates differentiation and maturation of T lymphocytes, activates CD3 +, CD4 +, CD8 + T lymphocytes, promotes supplements and maturity of pro-NK cells and enhances the killing effect of NK cells, thereby enhancing the body's immune function (11), inhibiting harmful inflammatory cytokine production, improving the efficacy of antibiotics and enhancing the rapid control of the infection. Therefore, $\mathrm{T} \alpha 1$ has the function to enhance cellular immunity and humoral immunity, promote immune responses and enhance therapeutic effects against infectious diseases caused by bacteria, viruses etc. Thymosin $\alpha 1$ has a bidirectional regulatory role. It can up-regulate beneficial cytokines such as IL-2 and interferon. Conversely, it can down-regulate harmful inflammatory cytokines such as TFN- $\alpha$ and IL- 6 . Thymosin $\alpha 1$ has a particularly important role in the pathophysiology process of inflammatory regulation, apoptosis and other processes. Studies have found that transcatheter arterial chemoembolization is relatively safe in the treatment of hepatocellular carcinoma with a significant effect (12). In the treatment process of malignant tumours, it can significantly improve CD4 $+/$ CD8 + ratio and the number and function of NK cells. In addition, it has a protective effect on $\mathrm{T}$ lymphocyte function and the haematopoietic function of bone marrow (13). In the treatment of hepatitis $C$ patients with cirrhosis, T $\alpha 1$ has achieved satisfactory results (14), but the effects of T $\alpha 1$ in the treatment of SAP are not clear. This study used T $\alpha 1$ to intervene in SD rats with SAP. The results showed that 12 hours after models were successfully established, the serum levels of TNF- $\alpha$, IL-1 $\beta$, IL- 6 and amylase increased significantly. Inflammatory cell infiltration, tissue oedema, haemorrhage and necrosis were observed in pancreatic tissues. Scores of pancreatic pathology increased significantly and were significantly higher than in Group A $(p<0.05)$. After treatment with T $\alpha 1$, amylase levels in serum and inflammatory cytokine levels in Group C decreased significantly compared with Group B $(p<0.05)$. The damage of the pancreas was alleviated significantly compared with Group B. The results of this experiment showed that SAP could reduce levels of inflammatory mediators and cytokines in SAP rats, as well as SAP pancreatic tissue necrosis and inflammatory cell infiltration. Thymosin $\alpha 1$ had a protective role. The results of this experiment provide new ideas and strategies for the clinical treatment of patients with SAP. The protection mechanism of T $\alpha 1$ merits further study.

\section{AUTHORS' NOTE}

The authors declare no conflict of interest. This study was supported by the Natural Science Foundation of Anhui Province Educational Committee (KJ2015B113by) and the Natural Science Foundation of Bengbu Medical College (BYKF1768).

\section{REFERENCES}

1. Frossard JL, Steer M, Pastor CM. Acute pancreatitis. Lancet 2008; 371: 143-52.

2. Wang YZ, Wang SW, Zhang YC, Sun ZJ. Protective effect of exogenous IGF-I on the intestinal mucosal barrier in rats with severe acute pancreatitis. World J Emerg Med 2012; 3: 213-20.

3. Mounzer R, Langmead CJ, Wu BU, Evans AC, Bishehsari F, Muddana $\mathrm{V}$ et al. Comparison of existing clinical scoring systems to predict persistent organ failure in patients with acute pancreatitis. Gastroenterology 2012; 142: 1476-82.

4. Garaci E. Thymosin alpha-1: a historical overview. Ann N Y Acad Sci 2007; 1112: 14-20.

5. Schmidt J, Rattner DW, Lewandrowski K, Compton CC, Mandavilli U, Knoefel WT et al. A better model of acute pancreatitis for evaluating therapy. Ann Surg 1992; 215: 44-56.

6. Mithofer K, Castillo CFD, Frick TW, Foitzik T, Bassi DG, Lewandrowski $\mathrm{KB}$ et al. Increased intrapancreatic trypsinogen activation in ischemiainduced experimental pancreatitis. Ann Surg 1995; 221: 364-71. 
7. Ogawa M. Acute pancreatitis and cytokines: 'second attack' by septic complication leads to organ failure. Pancreas 1998; 16: 312-5.

8. Sendler M, Dummer A, Weiss FU, Krüger B, Wartmann T, ScharffetterKochanek $\mathrm{K}$ et al. Tumour necrosis factor alpha secretion induces protease activation and acinar cell necrosis in acute experimental pancreatitis in mice. Gut 2013; 62: 430-9.

9. Wu X, Xu W, Feng X, He Y, Liu X, Gao Y et al. TNF - a mediated inflammatory macrophage polarization contributes to the pathogenesis of steroid-induced osteonecrosis in mice. Int J Immunopathol Pharmacol 2015; 28: 351-61.

10. Hicklin DJ, Marincola FM, Ferrone S. HLA class I antigen down-regulation in human cancers: T cell immunotherapy revives an old story. Mol Med Today 1999; 5: 178-86.
11. Moody TW. Thymosin alpha 1 as a chemopreventive agent in lung and breast cancer. Ann N Y Acad Sci 2007; 1112: 297-304.

12. Shuqun C, Mengchao W, Han C, Feng S, Jiahe Y, Wenming C et al. Combination transcatheter hepatic arterial chemoembolization with thymosin alpha 1 on recurrence prevention of hepatocellular carcinoma. Hepato-gastroenterology 2004; 51: 1445-7.

13. Naylor PH, Quadrini K, Garaci E, Rasi G, Hadden JW. Immunopharmacology of thymosin alpha 1 and cytokine synergy. Ann N Y Acad Sci 2007; 1112: 235-44.

14. Zhang Q, Fan L. Clinical analysis of 29 cases in which thymosin $\alpha 1$ treats hepatitis $\mathrm{C}$ patients with cirrhosis. Chinese Journal of Clinical Doctors (electronic version) 2013; 7: 11873-4. 